OPEN ACCESS

Edited by:

Åke Sjöholm,

Gävle Hospital, Sweden

Reviewed by:

Tatsuya Kin,

University of Alberta, Canada

Helen Thomas,

University of Melbourne, Australia

Rena Pawlick,

University of Alberta, Canada

*Correspondence:

Jialin Zhang

j|z2000@yeah.net

Specialty section:

This article was submitted to Diabetes: Molecular Mechanisms,

a section of the journal

Frontiers in Endocrinology

Received: 04 August 2020 Accepted: 04 November 2020 Published: 08 December 2020

Citation:

Yang Z, Li X, Zhang C, Sun N, Guo T, Lin J, Li F and Zhang J (2020) Amniotic Membrane Extract Protects Islets

From Serum-Deprivation Induced

Impairments and Improves Islet

Transplantation Outcome.

Front. Endocrinol. 11:587450.

doi: 10.3389/fendo.2020.587450

\section{Amniotic Membrane Extract Protects Islets From Serum-Deprivation Induced Impairments and Improves Islet Transplantation Outcome}

\author{
Zhaoming Yang, Xiaohang Li, Chengshuo Zhang, Ning Sun, Tingwei Guo, Jianzhen Lin, \\ Feng Li and Jialin Zhang *
}

Department of Hepatobiliary Surgery, The First Hospital of China Medical University, Shenyang, China

Islet culture prior to transplantation is a standard practice in many transplantation centers. Nevertheless, the abundant islet mass loss and function impairment during this serumdeprivation culture period restrain the success of islet transplantation. In the present study, we used a natural biomaterial derived product, amniotic membrane extract (AME), as medium supplementation of islet pretransplant cultivation to investigate its protective effect on islet survival and function and its underlying mechanisms, as well as the engraftment outcome of islets following AME treatment. Results showed that AME supplementation improved islet viability and function, and decreased islet apoptosis and islet loss during serum-deprived culture. This was associated with the increased phosphorylation of PI3K/Akt and MAPK/ERK signaling pathway. Moreover, transplantation of serum-deprivation stressed islets that were pre-treated with AME into diabetic mice revealed better blood glucose control and improved islet graft survival. In conclusion, AME could improve islet survival and function in vivo and in vitro, and was at least partially through increasing phosphorylation of PI3K/Akt and MAPK/ERK signaling pathway.

Keywords: amniotic membrane extract, serum-deprivation, apoptosis, islet transplantation, type 1 diabetes

\section{INTRODUCTION}

Islet transplantation is an effective $\beta$-cell replacement therapy that could help type 1 diabetes mellitus (T1DM) patients to achieve euglycemia (1). However, shortage of pancreas donors, the side effect of immunosuppression, and poor graft survival are some of the limitations related to this therapy $(2,3)$. Besides, early graft loss and the instant blood mediated inflammatory reaction (IBMIR) restrain the success of islet transplantation $(4,5)$. It is known that the achievement of insulin independence and the long-term outcome of islet transplantation are also determined by the quality and quantity of the initially transplanted islets (6).

Originally, islet culture is not included in the Edmonton Protocol, which required isolated islets to be infused within $4 \mathrm{~h}(2,7)$. This causes some difficulties in recipient preparation and islet quality control, and increases the risk of operation. Therefore in clinical islet transplantation, after isolation and purification, islets are cultured in vitro for $24-72 \mathrm{~h}(8-10)$ before transplantation to enable the 
quality control of the isolated islets, the pretreatment of recipients, and the transportation of islets to remote transplant centers $(11,12)$, and a 48 -h cultivation tend to be the standard practice accepted by most islet transplantation centers $(13,14)$. Nevertheless, islet viability, $\beta$-cell function were impaired, and approximately $10-20 \%$ of islet mass was lost during this period, which exacerbates the islet shortage and restrains the success of islet transplantation (15). Fetal bovine serum (FBS) is ideal for culturing islets, because it contains abundant growth factors and extracellular matrix components (16). However in clinical islet transplantation, human serum albumin (HSA) is used as a supplementation of the culture media (17) instead of FBS to avoid animal-derived factors, which causes a serum-deprived condition that may impair islet viability and function $(18,19)$. Therefore, it's urgent to explore strategies to prevent islet apoptosis during serum-deprived cultivation in vitro.

Human amniotic membrane (hAM), a commonly discarded tissue after Caesarean Section, has been utilized as a clinical therapeutic biomaterial for more than a century. Over recent years, several studies have investigated homogenates or extracts of amniotic membrane (AME) reporting them to contain abundant biomolecules that promote wound healing and tissue regeneration $(20,21)$, reduce inflammation and prevent oxidative stress-induced injury $(22,23)$, and promote cell proliferation, including epidermal growth factor (EGF), hepatocyte growth factor (HGF), heavy chain hyaluronic acid in complex with pentraxin 3 (HC-HA/PTX3), tissue inhibitor of metalloproteinases (TIMPs), IL-1 receptor antagonist (IL1RA), trombospondin-1 (TSP-1), Fas ligand (FasL), fibronectin, and collagen types I, III, IV, and V (24). Due to these properties and its low immunogenicity, AME has been used clinically in the treatment of acute or chronic chemical burns (25). Based on these findings, we hypothesize that amniotic membrane extract, containing abundance of growth factors and extracellular matrix components, can protect islets against serum deprivation induced impairments.

In this study, amniotic membrane extract was prepared and characterized, and its potential to protect islets during in vitro culture was examined. Specifically, amniotic membrane extract was added to the islet culture medium, and the viability, apoptosis, percent loss, and glucose-stimulated insulin secretion (GSIS) function of serum-deprived islets were evaluated. Cultured islets were further transplanted in the renal subcapsular space of syngenic diabetic recipients to assess the potential of AME treated islets in the regulation of blood glucose.

\section{METHODS AND MATERIALS}

\section{Animals}

Male C57BL/6 mice were obtained from Liaoning Changsheng biotechnology co., Ltd (Benxi, China). Six-to-eight-week old C57BL/6 mice (weighing 20-22 g), housed under Specific pathogen-free (SPF) conditions and fed ad libitum with food and water, were used as donor mice and diabetic recipients. All the surgeries were performed under isoflurane (RWD, Shenzhen,
China) inhalation anesthesia. This study was conducted in accordance with the National Institute of Health Guide and Use of Laboratory Animals and was approved by the Animal Care and Use Committee of China Medical University.

\section{Preparation and Characterization of Amniotic Membrane Extract}

All amniotic membranes were collected from the Department of Obstetrics of the First Affiliated Hospital of China Medical University. The study was approved by the Ethical Committee of the First Affiliated Hospital of China Medical University ([2019]2019-219-3), and informed consent was signed by all the participants choosing the elective caesarean section. Each prospective donor was screened for infectious diseases, and those who tested negative for HIV, hepatitis B, hepatitis C, cytomegalovirus, and syphilis were included in this study.

Amniotic membrane extract was prepared according to the methods described by Ebrahimi et al. (20). with some modifications. Briefly, hAM was washed with PBS (SH30256.01, Hyclone, USA) that contained 1,000 U/ml penicillin and $0.1 \mathrm{mg} / \mathrm{ml}$ streptomycin (pen/strep, P1400, Solarbio) three times to remove blood clots and was then cut into small pieces. Next, hAM was submerged in liquid nitrogen and manually ground into a fine powder. After weighing, they were mixed with PBS at a ratio of $1: 1(\mathrm{w} / \mathrm{v})$, after which the mixture was homogenized by a sonicator $(\mathrm{F} 6 / 10$, Jingxin, Shanghai, China) at $10,000 \mathrm{rpm}$ on ice for $1 \mathrm{~h}$. The homogenate was centrifuged at $4,000 \mathrm{~g}$ at $4^{\circ} \mathrm{C}$ for $10 \mathrm{~min}$, and the supernatant was collected and re-centrifuged at $15,000 \mathrm{~g}$ at $4^{\circ} \mathrm{C}$ for $5 \mathrm{~min}$. The final supernatant was collected and filtered through a $0.22-\mu \mathrm{m}$ filter.

Amniotic membrane was collected from 12 healthy donors and divided into four batches for the preparation of AME. The total protein in each batch of AME was assessed using a standard Bradford protein assay (P0006, Beyotime) according to the manufacturer's instructions. The concentrations of TIMP-1, EGF, HGF, and IL-1RA, as important amniotic membrane proteins for maintaining islet vitality (26-33), were assessed using commercially available ELISA kits (DEG00, DHG00, DTM100, and DRA00B, R\&D System Inc., Minneapolis, USA). The stability of the growth factors were assayed in freshly extracted AME and after 7 days to 1 month of storage at $-80^{\circ} \mathrm{C}$. The concentration of growth factors was also compared between cryopreserved AME (prepared 3 and 6 months ago respectively) and freshly prepared AME.

\section{Isolation and Culture of Islets}

Isolation of mouse islets was previously described (34). Briefly, the common bile duct was cannulated with a $31 \mathrm{G}$ steel needle, and the pancreas was inflated with $2-3 \mathrm{ml}$ collagenase $\mathrm{V}$ solution (1 mg/ml) (C9263, Sigma-Aldrich). Then, the perfused pancreas was acquired and digested in a $37^{\circ} \mathrm{C}$ thermostatic water bath for 20 min. Subsequently, the digestion was terminated with precooled Hank's balanced salt solution (HBSS) (14025134, Gibco, USA) containing 10\% fetal bovine serum (FBS) (10099141, Gibco, Australia) with vigorous agitation, and islets 
were purified on Ficoll gradients (density 1.108, 1.096, 1.069, and $1.037 \mathrm{~g} / \mathrm{ml}$ ) (F2637, Sigma-Aldrich).

Purified islets were collected and cultured in RPMI 1640 (Gibco, CA, USA) containing $100 \mathrm{U} / \mathrm{ml}$ penicillin and $0.01 \mathrm{mg} /$ $\mathrm{ml}$ streptomycin (P1400, Solarbio) at $37^{\circ} \mathrm{C}$ in a humidified atmosphere consisting of $95 \%$ air and $5 \% \mathrm{CO}_{2}$. For the serumdeprivation condition, islets were cultured in medium supplemented with $0.625 \%$ bovine serum albumin (BSA, A1933, Sigma-Aldrich) as previously described (33). To test the effects of AME on islet during cultivation, medium containing $0.625 \%$ BSA plus 0.1, 0.5, 1.0, $1.5 \mathrm{mg} / \mathrm{ml} \mathrm{AME} \mathrm{was}$ used to islet culture. Islets cultivated in medium containing $10 \%$ FBS (10099141, Gibco, Australia) were used as the positive control group.

\section{Assessment of Islet Viability}

After $48 \mathrm{~h}$ of cultivation, islets were assessed for viability using acridine orange (AO, Sigma, USA) and ethidium bromide (EB, Sigma, USA) as previously described (35). Briefly, $100 \mathrm{mg} / \mathrm{ml}$ acridine orange and $100 \mathrm{mg} / \mathrm{ml}$ ethidium bromide in PBS were mixed at a ratio of 1:1 to generate the working solution. The working solution was added to the islets containing medium (20 $\mu \mathrm{l}$ working solution per $\mathrm{ml}$ medium), and after 2-5 min incubation at room temperature, islet viability was examined by an inverted fluorescent microscope (Nikon Corporation). Viable cells were stained green, and viability was calculated as the percentage of the viable cells to total cells.

\section{Percent Islet Recovery}

To determine islet yield, islets prior to and post 48-h culture were harvested and counted as previously described (36). Briefly, aliquots from both experimental and control groups were stained with dithizone (Sigma Aldrich, USA) and counted. The ratio of total islets harvested $48 \mathrm{~h}$ post-culture relative to the number of islets harvested prior to culture was defined as the percentage of islet recovery.

\section{Assessment of Islet Apoptosis}

Apoptosis of the cultured islets was assessed by terminal deoxynucleotidyl transferase-mediated dUTP nick end labeling (TUNEL) assay (TUNEL)staining and flow cytometry as previously described (36-38). For TUNEL staining analysis, briefly, islets were collected and fixed in $4 \%$ paraformaldehyde, embedded in 3\% agar (A8190, Solarbio) to create a solid cellularmatrix interaction, then processed and embedded in paraffin. After deparaffinization and antigen heat retrieval, islet sections were washed with phosphate-buffered saline (PBS) supplemented with $5 \%$ bovine serum albumin (BSA, Solarbio), followed by incubation with guinea pig anti-insulin (ab7842, Abcam, UK) primary antibodies at 1:100 overnight at $4^{\circ} \mathrm{C}$. Then, samples were rinsed in PBS and incubated with goat anti-guinea pig (Alexa 488, Beyotime, Shanghai, China) secondary antibodies at 1:500 for $60 \mathrm{~min}$ at room temperature. Next, fluorescein isothiocyanate-dUTP with TdT enzyme (G3250, Promega, USA) was added and counterstained with the DAPI (Solarbio) in antifade mounting medium (Solarbio). Apoptosis was calculated as the percentage of the TUNEL-stained cells to the both insulin and nuclei positive cells using ImageJ software (downloaded from the NIH website [https://imagej.nih.gov/ij/]).

In addition, islet apoptosis was evaluated by flow cytometry using TUNEL Assay Kit - BrdU-Red (ab66110, Abcam) according to the manufacturer's instructions. After 48-h cultivation, 75-100 islets from respective samples were handpicked, washed with PBS twice, and dispersed into single cells by $0.1 \mathrm{mg} / \mathrm{ml}$ bovine trypsin (Sigma-Aldrich, USA) and $2 \mathrm{mmol} / \mathrm{l}$ EDTA in PBS for $5 \mathrm{~min}$ at $37^{\circ} \mathrm{C}$. Cells were then fixed with $4 \%$ formaldehyde and incubated for $30 \mathrm{~min}$ at room temperature. After being washed with PBS, cells were incubated in $70 \%$ ethanol for $30 \mathrm{~min}$ at $4^{\circ} \mathrm{C}$. Subsequently, cells were washed and incubated in DNA Labeling Solution for $60 \mathrm{~min}$ at $37^{\circ} \mathrm{C}$. After incubated in antibody solution for $30 \mathrm{~min}$ at room temperature in dark, 7-AAD/RNase A solution was added and cells were incubated for $30 \mathrm{~min}$ at room temperature in dark. Finally, cells were analyzed by flow cytometry (FACSCalibur; Becton Dickinson).

\section{Glucose Stimulated Insulin Secretion Assay}

After $48 \mathrm{~h}$ of cultivation, islets were collected and assessed for secretion function. Ten islets were preincubated in KrebsRinger-bicarbonate buffer (KRBB) containing $2.8 \mathrm{mM}$ glucose for $30 \mathrm{~min}$. After preincubation, islets were incubated in KRBB containing $2.8 \mathrm{mM}$ glucose (basal insulin secretion) for $1 \mathrm{~h}$ and in KRBB containing $16.8 \mathrm{mM}$ glucose for $1 \mathrm{~h}$ (GSIS) to collect the supernatants. Secreted insulin was determined using the Ultrasensitive Mouse Insulin Elisa kit (10-1249-01, Mercodia, Sweden). The stimulation index was calculated as the ratio of GSIS to basal insulin secretion (39).

\section{Western Blot}

Total cell extracts were analyzed by Western blot as previously described (40). Briefly, the total protein from treated cells (200 islets) was extracted using RIPA lysis buffer (P0013B, Beyotime, Shanghai, China) supplemented with protease inhibitors (P1006, Beyotime) and phosphatase inhibitors (P1046, Beyotime). Then, the protein concentration was determined using the BCA protein assay kit (P0010S, Beyotime). Twenty micrograms of total protein extracts were resolved by 10 or $12 \%$ SDS-PAGE (KGP113K, KeyGen Biotech. Co. Ltd., Nanjing, China) and transferred to PVDF membranes (Millipore, Temecula, CA, USA). Subsequently, membranes were blocked with 5\% non-fat dried milk solubilized in TBST for $2 \mathrm{~h}$ and probed with primary antibodies against p-AKT (Ser473) (4060, Cell Signaling Technology), AKT (9272, Cell Signaling Technology), p-ERK1/2 (9101, Cell Signaling Technology), ERK1/2 (9102, Cell Signaling Technology), Bcl2 (26593-1-AP, Proteintech), BAX (50599-2-Ig, Proteintech), Cleaved Caspase-3 (9664, Cell Signaling Technology), and $\beta$-actin (AF0003, Beyotime) at $4^{\circ} \mathrm{C}$ overnight. Finally, proteins were visualized using the ECL Western blot protocol (P0018, Beyotime) after incubation with the secondary antibodies for $2 \mathrm{~h}$ at room temperature. The intensity of bands was measured using the Image Lab 5.0 software. 


\section{In Vivo Islet Transplantation Underneath the Kidney Capsule}

Diabetic recipients were induced by intraperitoneal injection of streptozotocin (S0130, Sigma-Aldrich) at $180 \mathrm{mg} / \mathrm{kg}$ in sodium citrate buffer $(0.1 \mathrm{~mol} / \mathrm{L}, \mathrm{pH} 4.5)$ (Solarbio, Beijing, China). Recipients with non-fasting blood glucose exceeding $19.4 \mathrm{mmol} / \mathrm{L}$ for 2 consecutive days were considered diabetic. After 48 -h cultivation under different conditions (0.625\% BSA as BSA only group; $0.625 \% \mathrm{BSA}+0.5 \mathrm{mg} / \mathrm{ml} \mathrm{AME}$ as BSA + AME group; $10 \%$ FBS as FBS group), a marginal mass of islets (200 islets) was handpicked and transplanted underneath the kidney capsule of recipient mice under the anaesthetized condition. After islet transplantation, recipient mice were measured for non-fasting blood glucose using ACCUCHEK $^{\circledR}$ Performa glucometer (Roche, USA) every 3 days until the end of the study. Reversal of diabetes was defined as two consecutive readings of $<11.1 \mathrm{mmol} / \mathrm{L}$. After the 6 -week observation period, islet grafts were totally removed after reversal of diabetes by resection of the left kidney to confirm the graft dependent euglycemia. On the contrary, loss of graft function was defined as the non-fasting blood glucose exceeding $19.4 \mathrm{mmol} / \mathrm{L}$ for two consecutive readings. To confirm the graft-dependent euglycemia, nephrectomies were performed at the end of the study and non-fasting blood glucose was measured for 7 days to verify the recurrence of hyperglycemia.

\section{Intraperitoneal Glucose Tolerance Test}

To evaluate the metabolic function of the cultured islets in vivo, glucose tolerance tests were performed at 30 days post-transplantation. Following fasting overnight, glucose bolus $(2 \mathrm{~g} / \mathrm{kg}$ ) was intraperitoneally injected to recipient mice. Blood glucose was measured at $0,15,30,60,90$, $120 \mathrm{~min}$ after injection. Overt diabetic mice were excluded in this experiment.

\section{Histological Analysis}

Graft was retrieved at 42 days after transplantation (41). The samples were fixed, processed, embedded, sliced, and subjected to HE, immunohistochemistry, and immunofluorescence staining as previously described (42). Sequentially sliced sections were either stained with hematoxylin and eosin (HE) (Servicebio) or treated with immunohistochemistry or immunofluorescence staining. For immunohistochemistry staining, paraffin-embedded tissue sections were deparaffinized and hydrated using xylene and gradient of alcohol to water. Next, samples were blocked and incubated with insulin (ab7842, Abcam) primary antibody following antigen retrieval and endogenous peroxidase activity quenching. Finally, samples were incubated with the secondary antibody (Proteintech) and detected with the DAB Horseradish Peroxidase Color Development Kit (Beyotime) and counterstained with hematoxylin (MX Biotechnologies). Images were captured by light microscopy (Nikon, Japan). For immunofluorescence staining, samples were deparaffinized and after antigen retrieval and blocking by $5 \%$ bovine serum albumin (BSA, w/v;
Solarbio), samples were incubated with insulin (ab7842, Abcam, UK) and glucagon (2760, Cell Signaling Technology, USA) primary antibodies at $1: 100$ at $4^{\circ} \mathrm{C}$ overnight. Then samples were washed with $\mathrm{PBS}$ and incubated with the secondary antibodies consisting of goat anti-guinea pig (Alexa 488, Beyotime, Shanghai, China) at 1:500 and goat antirabbit (Alexa 555 , Beyotime) at 1:500. Finally, samples were counterstained with DAPI (Beyotime) in antifade mounting medium (Solarbio) and the images were acquired using a fluorescence microscope (Nikon, Japan).

\section{Graft Insulin Content}

After retrieval, islet bearing kidneys were stored at $-80^{\circ} \mathrm{C}$ until insulin analysis. Graft insulin content was measured, as previously described (43). Briefly, islet grafts were homogenized and sonicated at $4^{\circ} \mathrm{C}$ in $10 \mathrm{ml}$ of $2 \mathrm{mmol} / \mathrm{L}$ acetic acid containing $0.25 \%$ BSA for $2 \mathrm{~h}$. Next, homogenates were sonicated again and centrifuged at $10,000 \mathrm{~g}$ for $25 \mathrm{~min}$ at $4^{\circ} \mathrm{C}$, and the supernatant was collected. A total of $5 \mathrm{ml}$ acetic acid was added to the remaining pellets and extracted again by sonication and centrifugation, and the second supernatant was collected. Total volume was measured by a combination of the two supernatants, and the samples were assayed for insulin content using the Ultrasensitive Mouse Insulin Elisa kit (101249-01, Mercodia, Sweden).

\section{Statistical Analysis}

Statistical analysis was performed using Graph-Pad Prism 6 software (GraphPad Software, Inc., USA). Data are expressed as the mean \pm standard deviations. The differences between groups were analyzed by Student's unpaired t-test with twotailed $P$-values and one-way ANOVA, followed by Tukey's multiple comparisons test. A $P$-value of $<0.05$ was considered a statistically significant difference. All experiments were performed at least three times.

\section{RESULTS}

\section{Effects of AME on Serum-Deprived Islet Viability and Recovery In Vitro}

In order to investigate whether AME affects the viability of serum-deprived islets, $0.1-1.5 \mathrm{mg} / \mathrm{ml}$ AME were applied to islet culture media. After $48 \mathrm{~h}$ of cultivation, serum deprivation induced a significant decrease in cell viability compared to the whole serum group. Different concentrations $(0.1-1.0 \mathrm{mg} / \mathrm{ml})$ of AME protected islets against serum deprivation-induced impairment and maintained cell viability after a 48 -h in vitro culture, while $1.5 \mathrm{mg} / \mathrm{ml}$ AME showed no protective effects (Figures 1A, B). Additionally, islets were quantified to determine islet yield after $48 \mathrm{~h}$ cultivation. Results showed that serum-deprivation induced a significant islet loss $(33.05 \pm 5.11 \%$, BSA only group), while medium supplementation of AME ameliorated serum-deprivation induced islet loss (10.30 \pm 2.19 vs. $5.91 \pm 4.32 \%$, BSA + $0.5 \mathrm{mg} / \mathrm{ml} \mathrm{AME} v$. FBS only, $p>0.05$ ) (Figure 1C). 
A

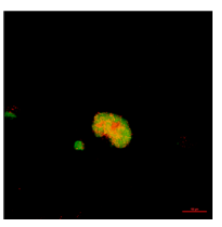

BSA only

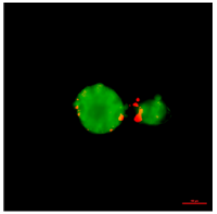

$\mathrm{BSA}+1.0 \mathrm{mg} / \mathrm{ml}$ AME

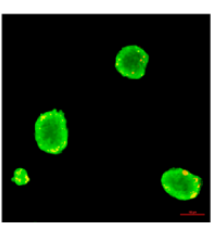

$\mathrm{BSA}+0.1 \mathrm{mg} / \mathrm{ml}$ AME

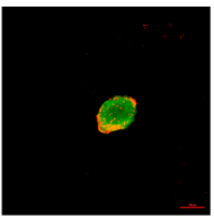

$\mathrm{BSA}+1.5 \mathrm{mg} / \mathrm{ml} \mathrm{AME}$

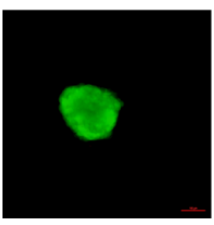

$\mathrm{BSA}+0.5 \mathrm{mg} / \mathrm{ml} \mathrm{AME}$

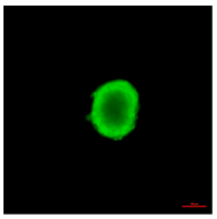

FBS only
B

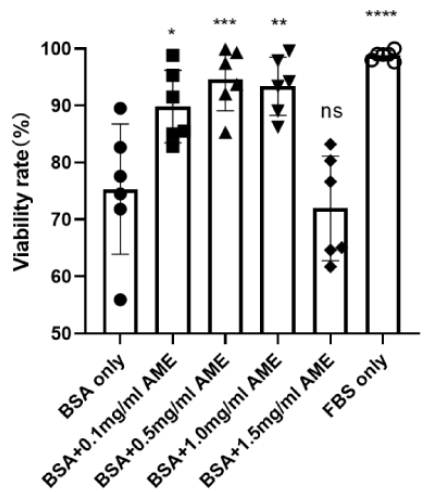

C

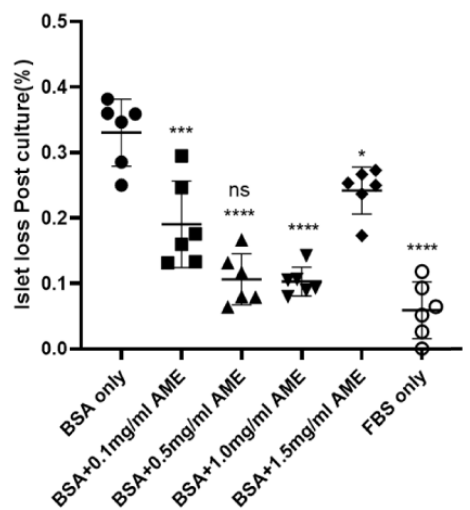

FIGURE 1 | AME significantly increased the viability and recovery of serum-deprived islets (A). Representative images are showing AO/EB staining of isolated islets after $48 \mathrm{~h}$ cultivation. Viable cells are stained as green (B). The percentage of viable cells was significantly increased with $\mathrm{AME}$ treatment $\left({ }^{*} \mathrm{p}<0.05\right.$, ${ }^{* \star} \mathrm{p}<0.01$, ${ }^{* * *} \mathrm{p}<0.001,{ }^{* \star *} \mathrm{p}<0.0001$ and ns vs. BSA only group, One-way ANOVA). Results are shown as means \pm SD of six independent experiments, with 75-100 islets/ condition for each independent experiment. Scale bar: $100 \mu \mathrm{m}$ (C). The percentage of islet loss post $48-\mathrm{h}$ cultivation in vitro $\left({ }^{\star \star \star} \mathrm{p}<0.001\right.$, ${ }^{\star \star \star \star} \mathrm{p}<0.0001$, ${ }^{* * \star *} p<0.0001,{ }^{*} p<0.05$, and ${ }^{* \star * *} p<0.0001$ vs. BSA only group, and ns vs. FBS only group, One-way ANOVA). Results are shown as means \pm SD of six independent experiments, with 75-100 islets/condition for each independent experiment.

\section{Apoptosis Rate Evaluated by TUNEL Staining and Flow Cytometry}

TUNEL staining was performed to evaluate the apoptosis rate of cultured islets in different groups. Results showed that AME protected islets from serum deprivation-induced impairment and significantly decreased apoptosis rate. We found that supplementation of AME at the concentration of $0.5 \mathrm{mg} / \mathrm{ml}$ mostly benefited the cultured islets, and there was no significant difference between groups of $0.5 \mathrm{mg} / \mathrm{ml}$ AME and FBS only. Though $1.5 \mathrm{mg} / \mathrm{ml}$ AME obviously decreased cellular apoptosis rate, its apoptosis rate was significantly higher than that in the 0.5 $\mathrm{mg} / \mathrm{ml}$ group (Figures 2A, B). In addition, a flow cytometry analysis was conducted to further verify islet cell apoptosis. There was a high level of DNA fragmentation (TUNEL positive staining) primarily due to the process of trypsin digestion. Results showed that a significant increase in DNA fragmentation was observed in serum-deprivation group compared to FBS only group ( $\mathrm{p}<0.001$ ), while cell death was not significantly increased in islets cultured in medium supplemented with $0.5 \mathrm{mg} / \mathrm{ml}$ AME group. Islets cultured in medium supplemented with $0.1,1.0$, and $1.5 \mathrm{mg} / \mathrm{ml} \mathrm{AME} \mathrm{also}$ showed significant decreases in apoptosis $(p<0.001)$ compared to serum-deprivation group (Figures 2C, D).

\section{Effects of AME on GSIS Function of Serum-Deprived Islet In Vitro}

To assess whether AME had a further protective effect on islet insulin secretory function in vitro, glucose-stimulated insulin secretion assay was performed after $48 \mathrm{~h}$ cultivation. Results showed that AME improved serum-deprived islet insulin secretory function at concentrations of $0.5 \mathrm{mg} / \mathrm{ml}(\mathrm{p}<0.0001)$ and $1.0 \mathrm{mg} / \mathrm{ml}(\mathrm{p}=0.0002)$ under high glucose $(16.8 \mathrm{mM})$ condition, but AME did not affect their insulin secretion levels under low glucose $(2.8 \mathrm{mM})$ condition. Further, we calculated the stimulation index of insulin and found that there were 2.07fold increase $(\mathrm{p}<0.0001)$ and 1.49 -fold increase $(\mathrm{p}=0.0014)$ in $0.5 \mathrm{mg} / \mathrm{ml} \mathrm{AME}$ group and $1.0 \mathrm{mg} / \mathrm{ml} \mathrm{AME}$ group respectively when compared to the serum-deprived (BSA only) group 

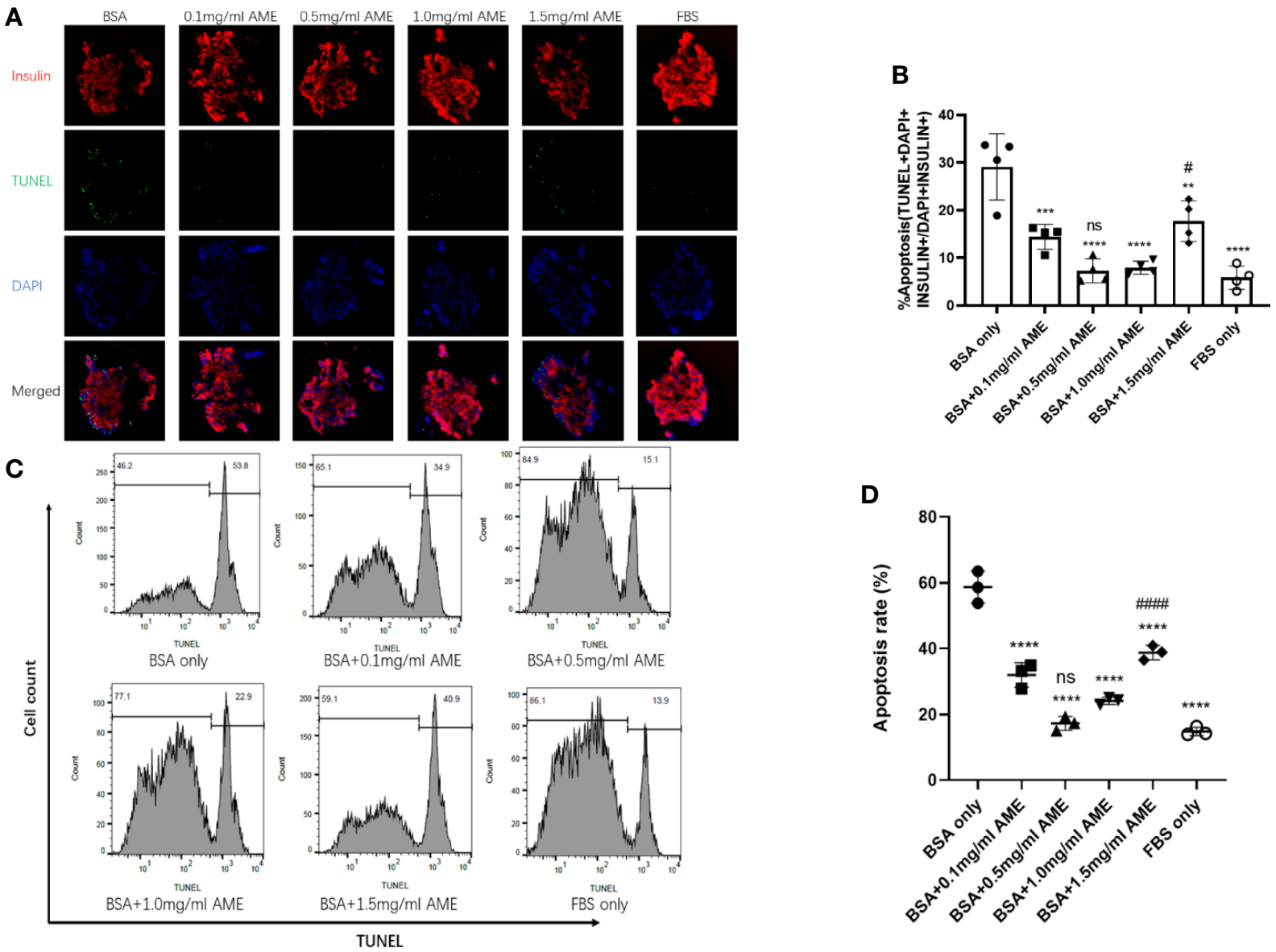

FIGURE 2 | AME significantly decreased the apoptosis rate of serum-deprived islets (A). Representative images are showing TUNEL staining of isolated islets after $48 \mathrm{~h}$ cultivation. Insulin (red), apoptosis (green), and nucleus/DAPI (blue) were stained for the analysis (B). The percentage of apoptosis was calculated as TUNEL +DAPI+Insulin+/DAPI+Insulin+. $\left({ }^{\star *} p<0.01,{ }^{\star * \star} p<0.001\right.$, and ${ }^{\star \star * \star} p<0.0001$ vs. BSA only group. ${ }^{\#} p<0.05$ vs. BSA + 0.5 mg/ml AME, and ns vs. FBS only group, One-way ANOVA). Results are shown as means \pm SD of four independent experiments, with 15-20 islets/condition for each independent experiment (C). Detection of DNA fragmentation (TUNEL staining) by flow cytometry (D). The percentage of apoptotic cells determined by flow cytometry following trypsin digestion. ${ }^{* \star \star \star} \mathrm{p}<$

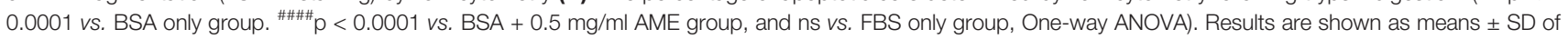
three independent experiments.

(Figure 3). The current data supported the protective effect of AME on serum-deprived islets, which peaked at the concentration of $0.5 \mathrm{mg} / \mathrm{ml}$; therefore, the concentration of 0.5 $\mathrm{mg} / \mathrm{ml}$ was used for subsequent experiments.

\section{The Protective Effect of AME Is Mediated by Increasing PI3K/Akt and ERK1/2 Expression}

The Ser/Thr kinase Akt (protein kinase B) is essential in PI3K/ Akt cascade and in promoting islet $\beta$-cell survival $(44,45)$. Hence, we investigated the effect of AME on Akt in islet cells after $48 \mathrm{~h}$ serum-deprivation. Western blot analysis revealed that AME significantly activated Akt phosphorylation compared to serum-deprived islet cells (Figures 4A, B). Given that the mitogen-activated protein kinase (MAPK) ERK1/2 can promote islet $\beta$-cells survival following extracellular matrix treatment (46), we performed western blot analysis of ERK1/2.
Results showed that AME significantly increased the phosphorylation of ERK1/2 compared to the serumdeprivation group (Figures 4C, D).

\section{Significant Increased Expression of Bcl2/ Bax Ratio in the Presence of AME}

To determine the effect of AME on the expression of apoptosisrelated proteins, Bcl2, Bax, and cleaved caspase- 3 was assessed by western blot analysis. Results showed that AME supplementation significantly increased the expression of $\mathrm{Bcl} 2$ compared to serum-deprivation group ( $\mathrm{p}<0.001$ ), while there was no significant difference in the expression of Bax between AME and serum-deprivation group. $\mathrm{Bcl} 2 / \mathrm{Bax}$ ratio was further analyzed and results showed that $\mathrm{Bcl} 2 / \mathrm{Bax}$ ratio was significantly increased in AME group compared to serumdeprivation group $(\mathrm{p}<0.01)$ (Figures 5A, B). Subsequently, the expression of cleaved caspase- 3 was evaluated and results 
A

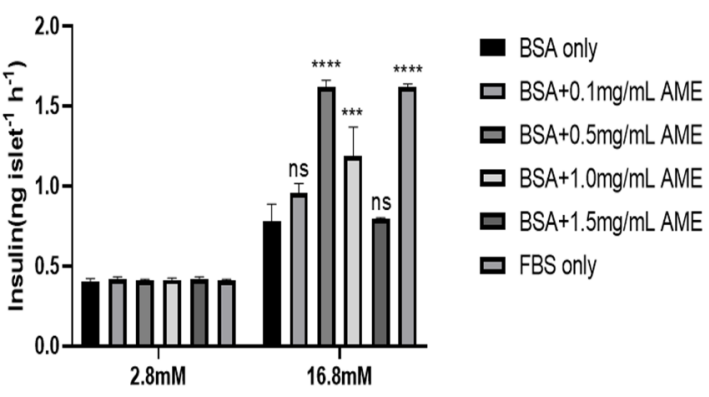

B

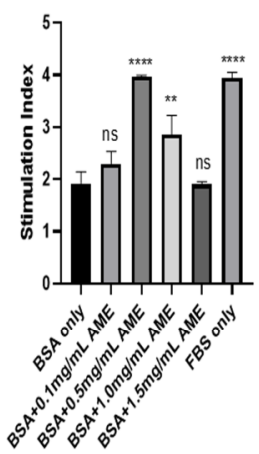

FIGURE 3 | Glucose-stimulated insulin release assay and stimulation index analysis (A). After $48 \mathrm{~h}$ cultivation, 10 islets were picked from each group and assayed for GSIS. The improvement of insulin secretory function by AME peaked at the concentration of $0.5 \mathrm{mg} / \mathrm{ml}{ }^{\left({ }^{\star \star *} \mathrm{p}\right.}<0.001,{ }^{\star \star \star \star} \mathrm{p}<0.0001$, and ns vs. BSA only group, Two-way ANOVA) (B). The stimulation index was calculated $\left({ }^{\star *} \mathrm{p}<0.01,{ }^{* \star \star *} \mathrm{p}<0.0001\right.$, and ns vs. BSA only group, One-way ANOVA). Results are shown as means $\pm S D$ of three independent experiments. showed that serum-deprivation induced a significantly increased expression of cleaved caspase-3(2.4-fold change) compared to normal FBS group, while supplementation of AME ameliorated this effect (Figures 5C, D).

\section{Non-Fasting Blood Glucose Measurements and Diabetes Reversal Rate Calculation}

To further determine the in vivo function of cultured islets, we transplanted equal amounts of islets into the renal subcapsular space of STZ-induced diabetic C57BL/6 mice after $48 \mathrm{~h}$ cultivation under different conditions (BSA only, BSA + AME, and FBS only). There were no significant differences among the initial non-fasting blood glucose levels of different groups (Sham group, $24.32 \pm 1.569$ $\mathrm{mM}$; BSA only group, $24.66 \pm 1.502 \mathrm{mM}$; BSA + AME group, $24.72 \pm 1.01 \mathrm{mM}$; FBS only group, $24.46 \pm 0.8597 \mathrm{mM})(\mathrm{p}>0.05$, Figure 6A). After transplantation, the BSA + AME group showed a significant decrease in the area under the curve (AUC) values compared to the BSA only group ( $554.1 \pm 27.59$ vs. $693.2 \pm 30.97$ $\mathrm{mmol} / \mathrm{L} / 42$ day, $\mathrm{p}<0.0001$, Figure $6 \mathbf{B})$. The AUC value of the BSA only group was significantly lower than that of the sham group $(693.2 \pm 30.97$ vs. $966.4 \pm 16.80 \mathrm{mmol} / \mathrm{L} / 42$ day, $\mathrm{p}<0.0001$, Figure 6B), which confirmed the effect of islet transplantation on blood glucose control. However, there was no significant difference between the BSA + AME and FBS only group in AUC values $(554.1 \pm 27.59$ vs. $527.7 \pm 25.76 \mathrm{mmol} / \mathrm{L} / 42$ day, $\mathrm{p}>0.05$, Figure 6B), and the AUC values of the BSA + AME and FBS only group were significantly higher than that of the naive group $(554.1 \pm$ 27.59 vs. $266.6 \pm 6.153 \mathrm{mmol} / \mathrm{L} / 42$ day, $\mathrm{p}<0.0001 ; 527.7 \pm 25.76$ vs. $266.6 \pm 6.153 \mathrm{mmol} / \mathrm{L} / 42$ day, $\mathrm{p}<0.0001$, Figure 6B).
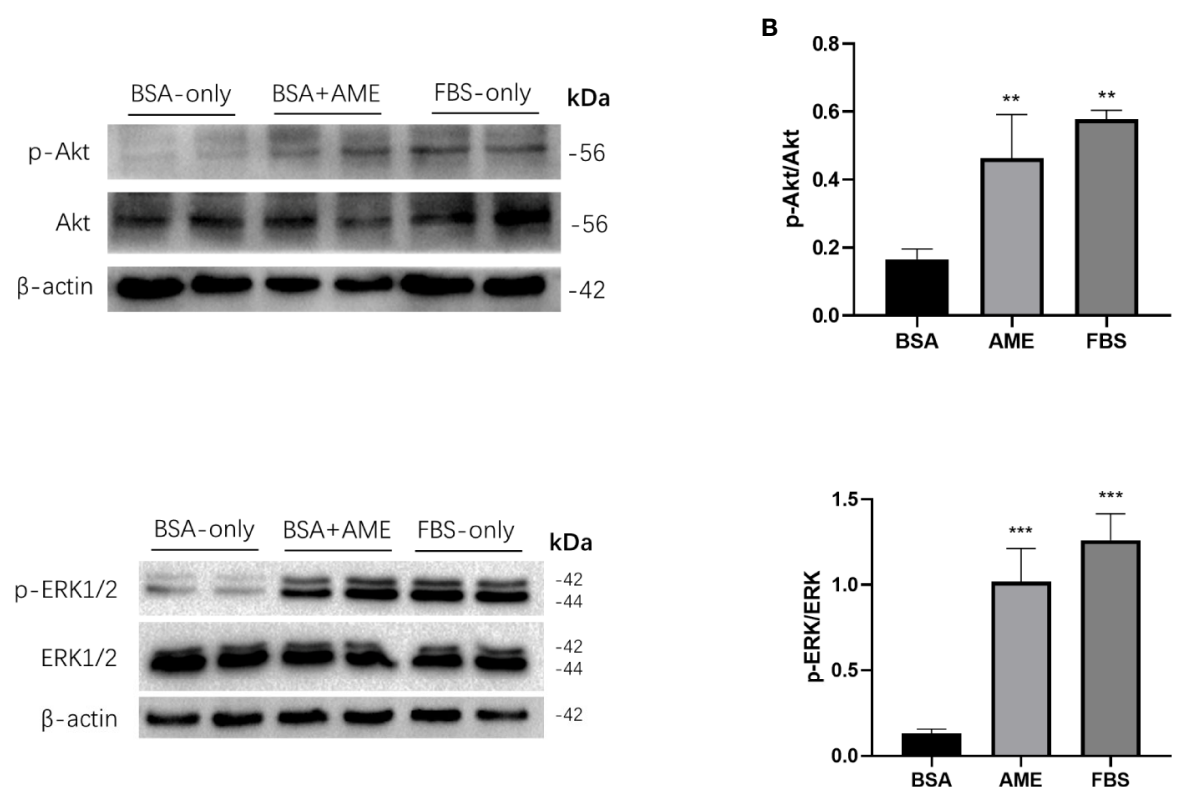

FIGURE 4 AME increased the phosphorylation of Akt and ERK1/2. (A, C) Protein levels of p-Akt, Akt, p-ERK1/2, and ERK1/2 were assessed by Western Blot (B). and (D) Quantification of protein levels showed the enhanced expression of Akt and ERK1/2 after AME $(0.5 \mathrm{mg} / \mathrm{ml})$ treatment $\left({ }^{* *} \mathrm{p}<0.01\right.$ and ${ }^{* \star *} \mathrm{p}<0.001 \mathrm{compared}$ to BSA only group, One-way ANOVA). Results are shown as means \pm SD of three independent experiments. 

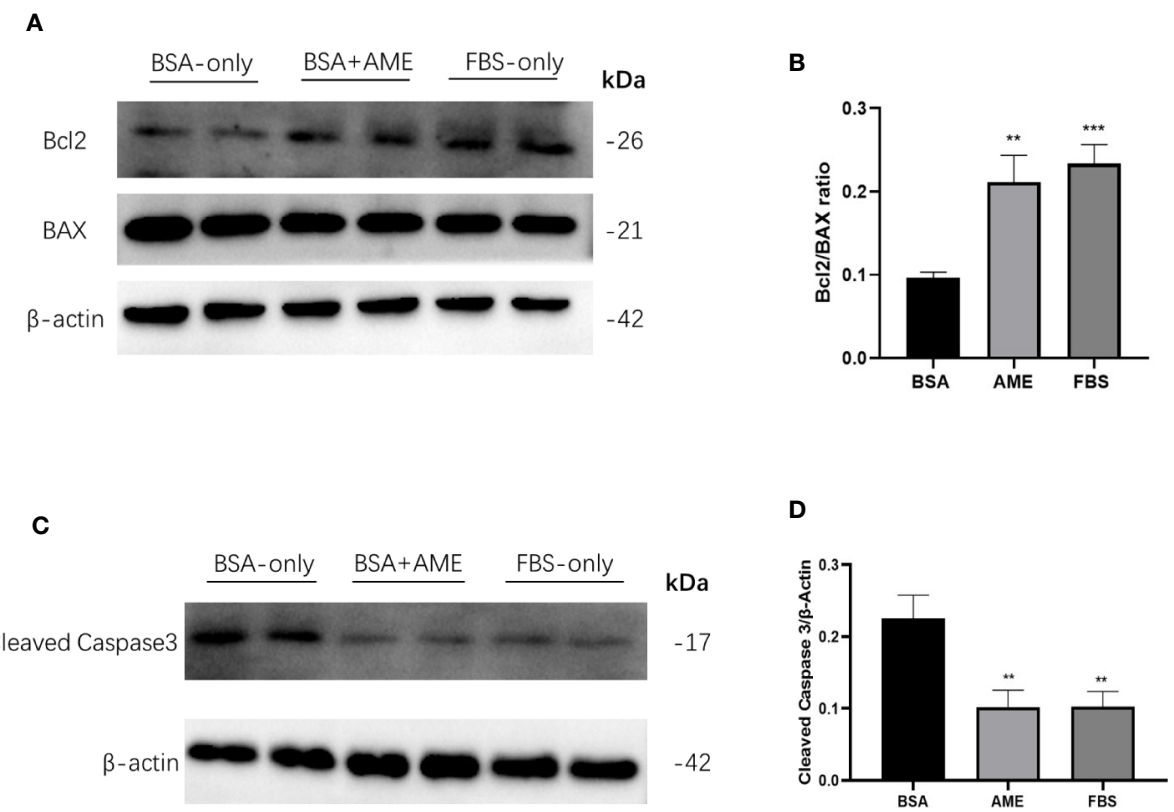

FIGURE 5 | AME increased Bcl2/BAX ratio and decreased the expression of cleaved caspase-3 (A). and (C) Protein levels of Bcl2, Bax, cleaved caspase-3, and $\beta$-actin were assessed by Western Blot (B). and (D) Quantification of protein levels showed the enhanced expression of Bcl2 after AME (0.5 mg/ml) treatment, while there was no significant change of the expression level of Bax ( $p>0.05$, One-way ANOVA). Further analysis of Bcl2/Bax ratio showed that AME significantly increased $\mathrm{Bcl} 2 /$ Bax ratio of serum-deprived islets $\left({ }^{* *} \mathrm{p}<0.01\right.$ and ${ }^{* * *} \mathrm{p}<0.001$ compared to BSA only group, one-way ANOVA). And the expression of cleaved caspase-3 was significantly decreased after AME treatment ( ${ }^{\star \star} \mathrm{p}<0.01 \mathrm{vs}$. BSA only group, One-way ANOVA). Results are shown as means \pm SD of three independent experiments.

The individual non-fasting blood glucose levels of BSA only and BSA + AME group during the 42-day monitoring were showed in Figure 6C. Meanwhile, body weight monitoring showed that graft recipients in BSA + AME group was significantly higher in body weight compared to graft recipients in BSA only group (AUC values, $948.6 \pm 11.63$ vs. $900.2 \pm 9.673 \mathrm{~g} / 42$ day, $\mathrm{p}<0.0001$, Figure 6D). Additionally, the diabetes reversal rates were significantly different between the BSA only and BSA + AME group ( $\mathrm{p}<0.05$, Figure $6 \mathrm{E})$.

\section{Intraperitoneal Glucose Tolerance Test}

As shown in Figure 7, the AUC value of the intraperitoneal glucose tolerance test of the BSA + AME group was significantly lower than that of the BSA only group $(1,712 \pm 51.39$ vs. $1,896 \pm$ $72.99 \mathrm{mmol} / \mathrm{L} / 120 \mathrm{~min}, \mathrm{p}<0.0001)$, which indicated that BSA + AME cultured islet graft presented a greater function of blood glucose control than BSA only cultured islet graft. However, there was no significant difference between the AUC values of the $\mathrm{BSA}+\mathrm{AME}$ and FBS only group $(1,712 \pm 51.39$ vs. $1,735 \pm 55.15$ $\mathrm{mmol} / \mathrm{L} / 120 \mathrm{~min}, \mathrm{p}>0.05)$.

\section{Histological Staining and Graft Insulin Content of the Islet Grafts}

Islet grafts were harvested and processed to histological analysis. Representative images of the HE staining, immunohistochemistry staining for insulin, and immunofluorescence staining for insulin and glucagon of islet grafts were displayed in Figure 8A, which indicated the survival of islet grafts under different precultured conditions.

To quantitatively analyze the islet graft survival, graft insulin content assay was conducted. As shown in Figure 8B, the graft insulin content of the BSA + AME group $(n=4)$ was significantly higher compared to the BSA only group $(\mathrm{n}=4)$ $(28.69 \pm 3.681$ vs. $4.681 \pm 0.6876 \mu \mathrm{g} / \mathrm{graft}, \mathrm{p}<0.0001)$, which suggested that AME supplementation during serum-deprived culture maintained islet viability and promoted islet graft survival. However, there was no significant difference between BSA + AME and FBS only group $(28.69 \pm 3.681$ vs. $29.09 \pm$ $1.008 \mu \mathrm{g} /$ graft, $\mathrm{p}>0.05)$.

\section{Concentrations of Growth Factors in Amniotic Membrane Extract}

In an attempt to elucidate the possible composition of AME, several growth factors reported to be beneficial for islet survival were assayed by commercially available ELISA kits. To assess the stability of AME, freshly prepared AME was assayed for the concentrations of growth factors pre- and post-storage at $-80^{\circ} \mathrm{C}$. Results showed that the concentrations of the growth factors tested were stable in the first month of storage at $-80^{\circ} \mathrm{C}$. Meanwhile, the concentrations of TIMP-1, EGF, HGF, and IL1RA were further tested by ELISA kits in freshly prepared AME and in cryopreserved AME that was prepared 3 and 6 months 
A

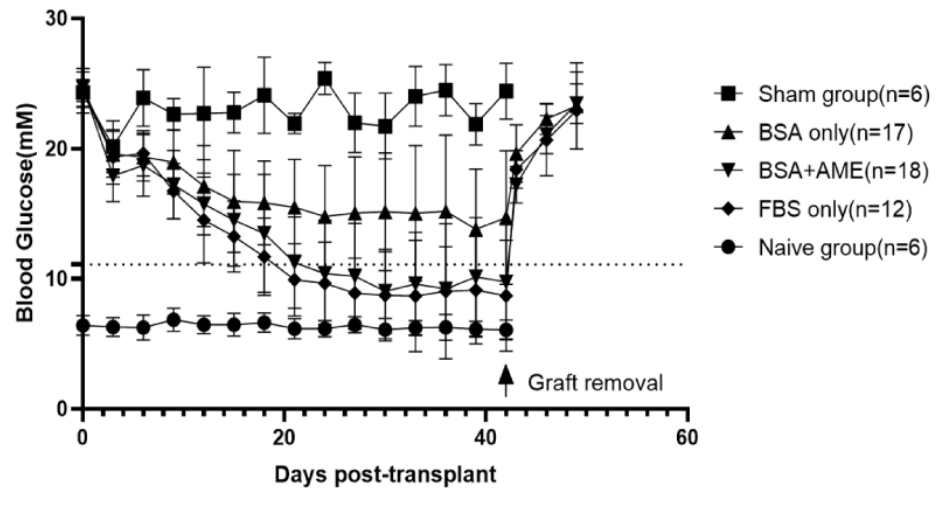

C

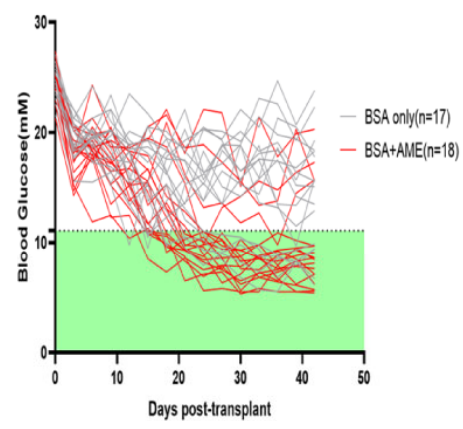

D

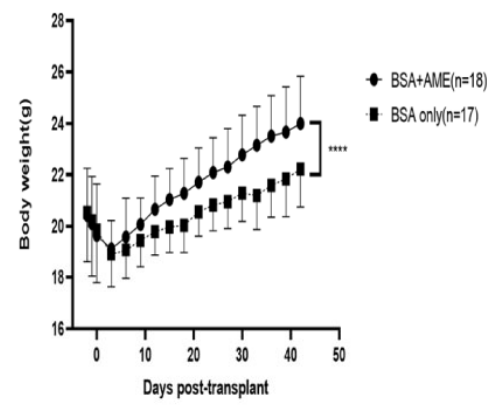

B

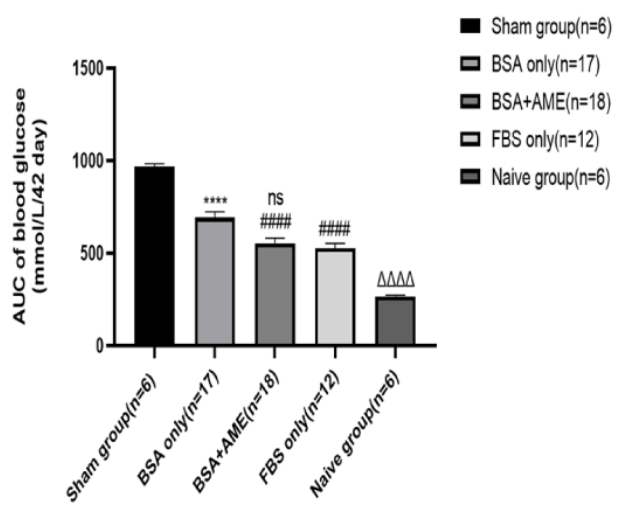

E

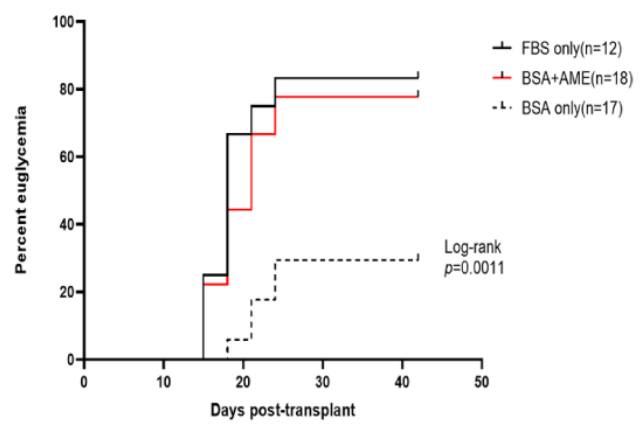

FIGURE 6 | Regulation of recipient blood glucose. Islets were cultured in different conditions (BSA only, BSA + AME [0.5 mg/ml], and FBS only) prior to transplantation. Nonfasting blood glucose was measured every 3 days post-transplantation (A). Non-fasting blood glucose curves of islet recipients and the control group. Data are shown as means \pm SD. The dotted line indicates the level of $11.1 \mathrm{mmol/}(\mathbf{B})$. AUC of non-fasting blood glucose, expressed as mmo/L/42days ("\#\#\# $\mathrm{p}<0.0001$ and $\mathrm{ns}$ when BSA + AME group [ $N=18$ ] was compared to BSA only [ $N=17$ ] and FBS only group [ $N=12$ ]; ${ }^{* \star \star *} p<0.0001$ when BSA only group was compared to the Sham group [N=6]; $\Delta \Lambda \Lambda p<0.0001$ when Naïve group [N = 6] was compared to BSA + AME and FBS only group, One-way ANOVA) (C). Non-fasting blood glucose of individual recipients in BSA only and BSA + AME group (D). Body weight monitoring of graft recipients in BSA + AME and BSA only group $\left({ }^{\star \star \star *} p<0.0001\right.$ when BSA + AME group [N $\left.=18\right]$ was compared to the BSA only $[N=17]$ group, Unpaired t-test) $(E)$. The percentage of recipients achieving euglycemia. $p=0.0016$ for the post hoc comparison of BSA only and BSA + AME group. $p=0.5270$ for the post hoc comparison of BSA+AME and FBS only group (Log-rank [Mantel-Cox] test).

ago respectively. The concentration of AME was $1.0 \mathrm{mg} / \mathrm{ml}$ in all samples tested by ELISA. Results showed that the concentrations of growth factors tested declined in cryopreserved AME, however the differences were not significant $(p>0.05)$ (Table 1).

\section{DISCUSSION}

Pretransplant islet culture has been adopted as a routine step to induce immunosuppressive therapy in the recipient, enable islet

TABLE 1 | Concentrations of growth factors in fresh and cryopreserved AME.

\begin{tabular}{|c|c|c|c|c|c|}
\hline \multirow{2}{*}{$\begin{array}{l}\text { Fresh AME } \\
\text { Growth factors }\end{array}$} & \multicolumn{5}{|c|}{ Cryopreserved AME } \\
\hline & Pre-Storage & 7 days & 1 month & 3 months & 6 months \\
\hline TIMP-1 (ng/ml) & $51.57 \pm 23.05$ & $48.80 \pm 19.38$ & $44.29 \pm 13.19$ & $45.27 \pm 13.85$ & $42.94 \pm 16.24$ \\
\hline EGF (pg/ml) & $199.93 \pm 14.03$ & $202.30 \pm 25.22$ & $197.20 \pm 22.42$ & $198.97 \pm 10.71$ & $179.73 \pm 10.50$ \\
\hline HGF (pg/ml) & $3035.02 \pm 212.33$ & $2957.10 \pm 116.56$ & $3004.13 \pm 279.92$ & $2903.95 \pm 111.35$ & $2764.74 \pm 151.51$ \\
\hline
\end{tabular}

All data are presented as mean $\pm S D$. 


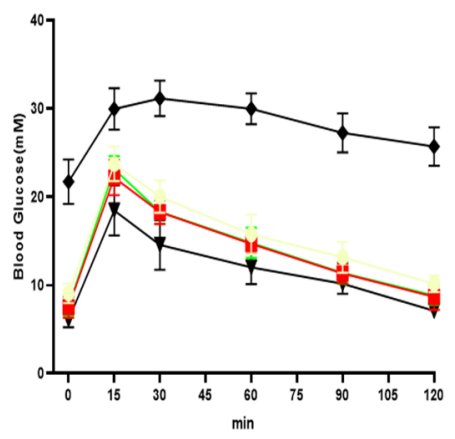

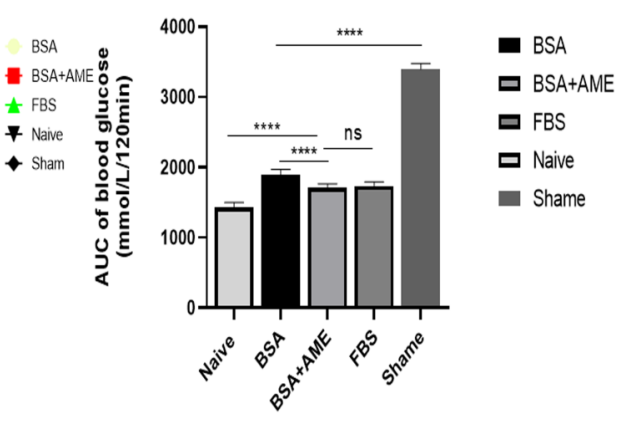

FIGURE 7 | Intraperitoneal glucose tolerance test of islet grafts pre-cultured under different conditions (A). Blood glucose was measured at 0, 15, 30, 60, 90, and 120 min after dextrose I.P. administration. Data points are shown as mean \pm SD (B). Areas under the curve of blood glucose tolerance test, expressed as mmol/L/ 120 min $\left(^{\star \star \star *} p<0.0001\right.$, ns and ${ }^{\star \star \star \star} p<0.0001$ when BSA + AME group [ $N=14$ ] was compared to BSA only [N=5], FBS only [N=10], and Naïve group [N=6], respectively. ${ }^{* \star *} p<0.0001$ when BSA only group was compared to the Sham group [N=6] One-way ANOVA).
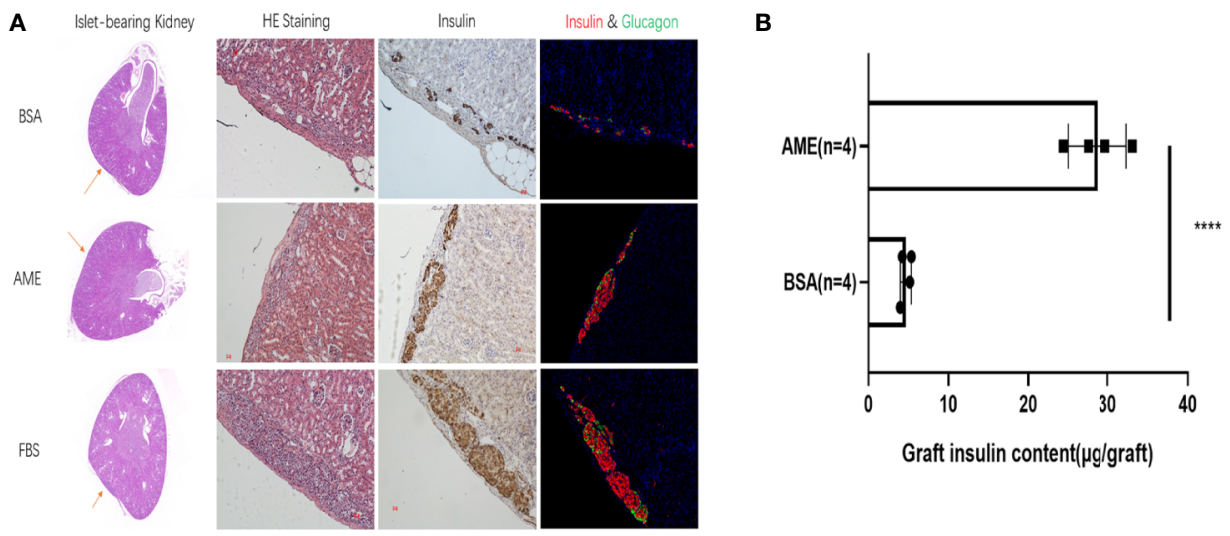

FIGURE 8 | Histological analysis of islet graft and islet graft insulin content assay (A). HE, immunohistochemistry, and immunofluorescence staining of islet grafts. Scale bar: $20 \mu \mathrm{m}$ (B). Islet grafts were harvested and homogenized to obtain the total insulin content of the grafts $\left(^{\star \star \star \star} \mathrm{p}<0.0001\right.$ when $\mathrm{BSA}+\mathrm{AME}$ [N $=4$ ] group was compared to BSA only [ $\mathrm{N}=4]$, Unpaired t-test).

quality control and islet shipment and cross-center transportation, increase islet purification, and minimize post-transplantation nonspecific inflammation (8-10, 47). However, isolated islets were stressed, and islet function was impaired during the in vitro cultivation period, which may result in unsatisfactory transplant outcomes. Various efforts have been made to preserve islet mass and function before transplantation, including supplementation of additives like green tea extract (48) and liraglutide (49); use of scaffolds or extracellular matrix (50-52), and modulation of the culture temperature and gas environment $(53,54)$. To the best of our knowledge, this is the first study that demonstrated how using human amniotic membrane extract as medium supplementation to improve islet viability and function. As described in the results, AME supplementation significantly improved islet viability and GSIS function, as well as reduced islet apoptosis rate and percent of islet loss after $48 \mathrm{~h}$ serum-deprived culture. And the PI3K/Akt and MAPK/ERK pathways were involved in the protective effect of
AME on islet as indicated by the increased expression of phosphorylated Akt and ERK1/2. Further, we found that AME supplementation increased the $\mathrm{Bcl} 2 / \mathrm{BAX}$ ratio in serumdeprived islet, and with decreased expression of cleaved caspase-3. Finally, we found that supplementation of AME in islet culture medium improved the engraftment efficiency of the cultured islet. Within the 6-week observation period, recipients in the AMEtreated-islet group showed a significant improvement in blood glucose control and graft insulin release function compared to the basal control group. In addition, there was a significant difference between the BSA+AME group and BSA only group in graft survival, which illustrated that AME-treated islets possessed a greater potential to survive and regulate recipient blood glucose compared to serum-deprived islets post-transplantation.

The amniotic membrane (AM) is a natural biomaterial that has been used in the treatment of various diseases, such as ophthalmology and burns disorder $(25,55)$. Previous studies 
have focused on the cells and scaffold from AM. And it has been reported that human amniotic epithelial cells (AECs) possess localized immune privilege in vitro, thus having a potential implication for islet transplantation (56). Another study engineered insulin-producing organoids from islet and amniotic epithelial cells, which markedly enhanced engraftment viability and graft function (57). Further, it was reported that by co-infusing human amniotic epithelial cells and islets into decellularized AM and then transplanting it into diabetic mice, it is possible to achieve good engraftment outcomes (58). These studies implicate the application potential of AME in islet transplantation. Recently, increasing studies have explored the properties of AME due to its extensive biomolecules and low immunogenicity, and result shown that AME promoted limbal stem cell proliferation and corneal epithelium healing (20), protected primary human corneal epithelial (HCE) cells and human limbal cells from oxidative stress (22). More recently, it was reported that amniotic membrane extract protected $\mathrm{H} 9 \mathrm{c} 2$ cardiomyoblasts against hypoxia-induced apoptosis $(23,59)$. Taken together, these suggest that AME has cytoprotective effects and might serve as cytoprotective agents in islet transplantation.

The PI3K/Akt pathway plays a key role in mediating cell proliferation, survival, and metabolism (60). It was reported that growth factors like hepatocyte growth factor and epidermal growth factor could activate PI3K/Akt signaling pathway, leading to cell growth and survival $(26,61)$. In particular, studies have shown that activation of Akt has a pivotal role in isolated islet survival during in vitro culture (44, 45, 62-64). Another signal pathway involved in the regulation of isolated islet survival is the MAPK pathway (65). The MAPK family includes three major subgroups: extracellular signal-regulated kinases (ERKs), c-Jun N-terminal kinases (JNKs), and p38 MAPK (p38). It was reported that the extracellular matrix derived from $804 \mathrm{G}$ cells protected islet $\beta$-cells against apoptosis via the activation of Akt and ERK (46). Our previous study also showed that increased ERK activation had a protective effect on islet $\beta$-cells (66). Considering that AME is a mixture of growth factors and extracellular matrix components, we inferred that the protective effect of AME on islet might involve PI3K/Akt and MAPK/ERK pathway, which is also consistent with the results of our study.

Nevertheless, there are some limitations to the present study. Firstly, we characterized AME by measuring the concentrations of several growth factors reporting to have prosurvival effects on islet. However, it was reported that AME at high concentrations had a negative impact on cell growth (20), thus suggesting a potential presence of some components that could impair cell viability at certain levels. Our data showed that AME no longer protected islet at the concentration of $1.5 \mathrm{mg} / \mathrm{ml}$, implicating that there existed some components harmful to islet at high concentrations. Therefore, it is necessary to define the exact constituents of AME in our further investigation. Then, primary islets isolated from C57BL/6 mice were used in this study, which may differ from primary human islets. With some ethical and technical issues, we could not get access to human islets currently. Finally, considering AME was a mixture, it was not suitable to be cotransplanted with islets into renal subcapsular space nor portal vein, which hindered the observation of the AME effects on the islet in vivo. While, we are investigating the possibility of AME combined with tissue engineering during islet transplantation in our ongoing experiments.

In conclusion, the present study demonstrated that supplementation of AME during serum-deprived pretransplant culture improved isolated islet survival and function, which consequently improved islet engraftment outcomes. The PI3K/ Akt and MAPK/ERK had an essential role in the protective effect of AME. Therefore, our results suggest that AME might serve as a potentially effective medium supplement in the pretransplant culture of islets isolated for clinical transplantation.

\section{DATA AVAILABILITY STATEMENT}

The raw data supporting the conclusions of this article will be made available by the authors, without undue reservation, to any qualified researcher.

\section{ETHICS STATEMENT}

The studies involving human participants were reviewed and approved by Ethical Committee of the First Affiliated Hospital of China Medical University. The patients/participants provided their written informed consent to participate in this study. The animal study was reviewed and approved by Animal Care and Use Committee of China Medical University.

\section{AUTHOR CONTRIBUTIONS}

Conception and design of the study: ZY and JZ. Acquisition of data: ZY, TG, and FL. Analysis and interpretation of data: ZY and JL. Drafting or revising the manuscript: ZY, XL, CZ, NS, JL, and JZ. All authors contributed to the article and approved the submitted version.

\section{FUNDING}

This work was supported by the program of Liaoning provincial science and technology department (Grant no.2017225031).

\section{ACKNOWLEDGMENTS}

We thank Tao Meng and Hongxin Lang for technical assistance. We also acknowledge the support of the Department of Obstetrics at the First Affiliated Hospital of China Medical University. 


\section{REFERENCES}

1. Shapiro AM, Pokrywczynska M, Ricordi C. Clinical pancreatic islet transplantation. Nat Rev Endocrinol (2017) 13(5):268-77. doi: 10.1038/ nrendo.2016.178

2. Shapiro AM, Lakey JR, Ryan EA, Korbutt GS, Toth E, Warnock GL, et al. Islet transplantation in seven patients with type 1 diabetes mellitus using a glucocorticoid-free immunosuppressive regimen. N Engl J Med (2000) 343 (4):230-8. doi: 10.1056/NEJM200007273430401

3. Vantyghem MC, de Koning EJP, Pattou F, Rickels MR. Advances in $\beta$-cell replacement therapy for the treatment of type 1 diabetes. Lancet (2019) 394 (10205):1274-85. doi: 10.1016/S0140-6736(19)31334-0

4. Eich T, Eriksson O, Lundgren T. Visualization of early engraftment in clinical islet transplantation by positron-emission tomography. N Engl J Med (2007) 356(26):2754-5. doi: 10.1056/NEJMc070201

5. Pepper AR, Bruni A, Pawlick R, Wink J, Rafiei Y, Gala-Lopez B, et al. Engraftment Site and Effectiveness of the Pan-Caspase Inhibitor F573 to Improve Engraftment in Mouse and Human Islet Transplantation in Mice. Transplantation (2017) 101(10):2321-9. doi: 10.1097/TP.000000000000 1638

6. Vantyghem M-C, Kerr-Conte J, Arnalsteen L, Sergent G, Defrance F, Gmyr V, et al. Primary graft function, metabolic control, and graft survival after islet transplantation. Diabetes Care (2009) 32(8):1473-8. doi: 10.2337/dc08-1685

7. Shapiro AMJ, Ricordi C, Hering BJ, Auchincloss H, Lindblad R, Robertson RP, et al. International trial of the Edmonton protocol for islet transplantation. New Engl J Med (2006) 355(13):1318-30. doi: 10.1056/NEJMoa061267

8. Murdoch TB, McGhee-Wilson D, Shapiro AM, Lakey JR. Methods of human islet culture for transplantation. Cell Transplant (2004) 13(6):605-17. doi: $10.3727 / 000000004783983602$

9. Daoud J, Rosenberg L, Tabrizian M. Pancreatic islet culture and preservation strategies: advances, challenges, and future outlook. Cell Transplant (2010) 19 (12):1523-35. doi: 10.3727/096368910X515872

10. Fraker C, Montelongo J, Szust J, Khan A, Ricordi C. The use of multiparametric monitoring during islet cell isolation and culture: a potential tool for in-process corrections of critical physiological factors. Cell Transplant (2004) 13(5):497-502. doi: 10.3727/000000004783983648

11. Noguchi H, Miyagi-Shiohira C, Kurima K, Kobayashi N, Saitoh I, Watanabe $\mathrm{M}$, et al. Islet Culture/Preservation Before Islet Transplantation. Cell Med (2015) 8(1-2):25-9. doi: 10.3727/215517915X689047

12. Ichii H, Sakuma Y, Pileggi A, Fraker C, Alvarez A, Montelongo J, et al. Shipment of human islets for transplantation. Am J Transplant (2007) 7 (4):1010-20. doi: 10.1111/j.1600-6143.2006.01687.x

13. Hering BJ, Kandaswamy R, Ansite JD, Eckman PM, Nakano M, Sawada T, et al. Single-donor, marginal-dose islet transplantation in patients with type 1 diabetes. Jama (2005) 293(7):830-5. doi: 10.1001/jama.293.7.830

14. Froud T, Ricordi C, Baidal DA, Hafiz MM, Ponte G, Cure P, et al. Islet transplantation in type 1 diabetes mellitus using cultured islets and steroidfree immunosuppression: Miami experience. Am J Transplant (2005) 5 (8):2037-46. doi: 10.1111/j.1600-6143.2005.00957.x

15. Kin T, Senior P, O'Gorman D, Richer B, Salam A, Shapiro AM. Risk factors for islet loss during culture prior to transplantation. Transpl Int (2008) 21 (11):1029-35. doi: 10.1111/j.1432-2277.2008.00719.x

16. Holmes MA, Clayton HA, Chadwick DR, Bell PR, London NJ, James RF. Functional studies of rat, porcine, and human pancreatic islets cultured in ten commercially available media. Transplantation (1995) 60(8):854-60. doi: 10.1097/00007890-199510270-00016

17. Hering BJ, Kandaswamy R, Harmon JV, Ansite JD, Clemmings SM, Sakai T, et al. Transplantation of cultured islets from two-layer preserved pancreases in type 1 diabetes with anti-CD3 antibody. Am J Transplant (2004) 4(3):390401. doi: 10.1046/j.1600-6143.2003.00351.x

18. Avgoustiniatos ES, Scott WE 3rd, Suszynski TM, Schuurman HJ, Nelson RA, Rozak PR, et al. Supplements in human islet culture: human serum albumin is inferior to fetal bovine serum. Cell Transplant (2012) 21(12):2805-14. doi: 10.3727/096368912X653138

19. Nacher M, Estil Les E, Garcia A, Nadal B, Pairo M, Garcia C, et al. Human Serum Versus Human Serum Albumin Supplementation in Human Islet Pretransplantation Culture: In Vitro and In Vivo Assessment. Cell Transplant (2016) 25(2):343-52. doi: 10.3727/096368915X688119
20. Shayan Asl N, Nejat F, Mohammadi P, Nekoukar A, Hesam S, Ebrahimi M, et al. Amniotic Membrane Extract Eye Drop Promotes Limbal Stem Cell Proliferation and Corneal Epithelium Healing. Cell J (2019) 20(4):459-68. doi: 10.22074/cellj.2019.5423

21. Wu MF, Stachon T, Langenbucher A, Seitz B, Szentmary N. Effect of Amniotic Membrane Suspension (AMS) and Amniotic Membrane Homogenate (AMH) on Human Corneal Epithelial Cell Viability, Migration and Proliferation In Vitro. Curr Eye Res (2017) 42(3):351-7. doi: 10.1080/ 02713683.2016.1192193

22. Dudok DV, Nagdee I, Cheung K, Liu H, Vedovelli L, Ghinelli E, et al. Effects of amniotic membrane extract on primary human corneal epithelial and limbal cells. Clin Exp Ophthalmol (2015) 43(5):443-8. doi: 10.1111/ ceo. 12480

23. Faridvand Y, Nozari S, Vahedian V, Safaie N, Pezeshkian M, Haddadi P, et al. Nrf2 activation and down-regulation of HMGB1 and MyD88 expression by amnion membrane extracts in response to the hypoxia-induced injury in cardiac H9c2 cells. BioMed Pharmacother (2019) 109:360-8. doi: 10.1016/ j.biopha.2018.10.035

24. Murri MS, Moshirfar M, Birdsong OC, Ronquillo YC, Ding Y, Hoopes PC, et al. Amniotic membrane extract and eye drops: a review of literature and clinical application. Clin Ophthalmol (2018) 12:1105-12. doi: 10.2147/ OPTH.S165553

25. Liang L, Li W, Ling S, Sheha H, Qiu W, Li C, et al. Amniotic membrane extraction solution for ocular chemical burns. Clin Exp Ophthalmol (2009) 37 (9):855-63. doi: 10.1111/j.1442-9071.2009.02159.x

26. Fiaschi-Taesch N, Stewart AF, Garcia-Ocaña A. Improving islet transplantation by gene delivery of hepatocyte growth factor (HGF) and its downstream target, protein kinase B (PKB)/Akt. Cell Biochem Biophys (2007) 48(2-3):191-9. doi: 10.1007/s12013-007-0024-7

27. García-Ocaña A, Vasavada RC, Cebrian A, Reddy V, Takane KK, LópezTalavera JC, et al. Transgenic overexpression of hepatocyte growth factor in the beta-cell markedly improves islet function and islet transplant outcomes in mice. Diabetes (2001) 50(12):2752-62. doi: 10.2337/diabetes.50.12.2752

28. Han X, Sun Y, Scott S, Bleich D. Tissue inhibitor of metalloproteinase-1 prevents cytokine-mediated dysfunction and cytotoxicity in pancreatic islets and beta-cells. Diabetes (2001) 50(5):1047-55. doi: 10.2337/diabetes.50.5.1047

29. Jiang $\mathrm{H}$, Zhu H, Chen X, Peng Y, Wang J, Liu F, et al. TIMP-1 transgenic mice recover from diabetes induced by multiple low-dose streptozotocin. Diabetes (2007) 56(1):49-56. doi: 10.2337/db06-0710

30. Lee HY, Yea K, Kim J, Lee BD, Chae YC, Kim HS, et al. Epidermal growth factor increases insulin secretion and lowers blood glucose in diabetic mice. J Cell Mol Med (2008) 12(5A):1593-604. doi: 10.1111/j.15824934.2007.00169.x

31. Wang M, Racine JJ, Song X, Li X, Nair I, Liu H, et al. Mixed chimerism and growth factors augment $\beta$ cell regeneration and reverse late-stage type 1 diabetes. Sci Trans Med (2012) 4(133):133ra59. doi: 10.1126/scitranslmed. 3003835

32. Danobeitia JS, Hanson MS, Chlebeck P, Park E, Sperger JM, Schwarznau A, et al. Donor Pretreatment With IL-1 Receptor Antagonist Attenuates Inflammation and Improves Functional Potency in Islets From Brain-Dead Nonhuman Primates. Cell Transplant (2015) 24(9):1863-77. doi: 10.3727/ 096368914X681045

33. Jin SM, Shim W, Oh BJ, Oh SH, Yu SJ, Choi JM, et al. Anakinra Protects Against Serum Deprivation-Induced Inflammation and Functional Derangement in Islets Isolated From Nonhuman Primates. Am J Transplant (2017) 17(2):365-76. doi: 10.1111/ajt.13953

34. Li F, Jiao A, Li X, Zhang C, Sun N, Zhang J. Survival and Metabolic Function of Syngeneic Mouse Islet Grafts Transplanted Into the Hepatic Sinus Tract. Transplantation (2018) 102(11):1850-6. doi: 10.1097/TP.0000000000002289

35. Bai-Feng L, Yong-Feng L, Ying C. Silencing inducible nitric oxide synthase protects rat pancreatic islet. Diabetes Res Clin Pract (2010) 89(3):268-75. doi: 10.1016/j.diabres.2010.05.013

36. Gamble A, Pawlick R, Pepper AR, Bruni A, Adesida A, Senior PA, et al. Improved islet recovery and efficacy through co-culture and cotransplantation of islets with human adipose-derived mesenchymal stem cells. PloS One (2018) 13(11):e0206449. doi: 10.1371/journal.pone.0206449

37. McKenzie MD, Carrington EM, Kaufmann T, Strasser A, Huang DCS, Kay TWH, et al. Proapoptotic BH3-only protein Bid is essential for death receptor- 
induced apoptosis of pancreatic beta-cells. Diabetes (2008) 57(5):1284-92. doi: $10.2337 / \mathrm{db} 07-1692$

38. Cao X, Gao Z, Robert CE, Greene S, Xu G, Xu W, et al. Pancreatic-derived factor (FAM3B), a novel islet cytokine, induces apoptosis of insulin-secreting beta-cells. Diabetes (2003) 52(9):2296-303. doi: 10.2337/diabetes.52.9.2296

39. Auer VJ, Janas E, Ninichuk V, Eppler E, Weiss TS, Kirchner S, et al. Extracellular factors and immunosuppressive drugs influencing insulin secretion of murine islets. Clin Exp Immunol (2012) 170(2):238-47. doi: 10.1111/j.1365-2249.2012.04645.x

40. Lin J, Jiao A, Lv W, Zhang C, Shi Y, Yang Z, et al. Pentapeptide Protects INS-1 Cells From hIAPP-Mediated Apoptosis by Enhancing Autophagy Through mTOR Pathway. Front Pharmacol (2019) 10:896. doi: 10.3389/fphar.2019.00896

41. Lee HS, Song S, Shin DY, Kim GS, Lee JH, Cho CW, et al. Enhanced effect of human mesenchymal stem cells expressing human TNF-alphaR-Fc and HO-1 gene on porcine islet xenotransplantation in humanized mice. Xenotransplantation (2018) 25(1). doi: 10.1111/xen.12342

42. Jiao A, Li F, Zhang C, Lv W, Chen B, Zhang J, et al. Simulated Cholinergic Reinnervation of (INS-1) Cells: Antidiabetic Utility of Heterotypic Pseudoislets Containing Cell and Cholinergic Cell. Int J Endocrinol (2018) 2018:1505307. doi: 10.1155/2018/1505307

43. Hayward JA, Ellis CE, Seeberger K, Lee T, Salama B, Mulet-Sierra A, et al. Cotransplantation of Mesenchymal Stem Cells With Neonatal Porcine Islets Improve Graft Function in Diabetic Mice. Diabetes (2017) 66(5):1312-21. doi: $10.2337 / \mathrm{db} 16-1068$

44. Aikin R, Hanley S, Maysinger D, Lipsett M, Castellarin M, Paraskevas S, et al. Autocrine insulin action activates Akt and increases survival of isolated human islets. Diabetologia (2006) 49(12):2900-9. doi: 10.1007/s00125-0060476-0

45. Zhang Y, He S, Du X, Jiang Y, Tian B, Xu S. Rapamycin suppresses hypoxia/ reoxygenation-induced islet injury by up-regulation of miR-21 via PI3K/Akt signalling pathway. Cell Prolif (2017) 50(1):e12306. doi: 10.1111/cpr.12306

46. Hammar E, Parnaud G, Bosco D, Perriraz N, Maedler K, Donath M, et al. Extracellular matrix protects pancreatic beta-cells against apoptosis: role of short- and long-term signaling pathways. Diabetes (2004) 53(8):2034-41. doi: 10.2337/diabetes.53.8.2034

47. Gaber AO, Fraga DW, Callicutt CS, Gerling IC, Sabek OM, Kotb MY, et al. Improved in vivo pancreatic islet function after prolonged in vitro islet culture. Transplantation (2001) 72(11):1730-6. doi: 10.1097/00007890200112150-00005

48. Zhang G, Matsumoto S, Hyon S-H, Qualley SA, Upshaw L, Strong DM, et al. Polyphenol, an extract of green tea, increases culture recovery rates of isolated islets from nonhuman primate pancreata and marginal grade human pancreata. Cell Transplant (2004) 13(2):145-52. doi: 10.3727/000000004773301825

49. Langlois A, Dal S, Vivot K, Mura C, Seyfritz E, Bietiger W, et al. Improvement of islet graft function using liraglutide is correlated with its anti-inflammatory properties. Br J Pharmacol (2016) 173(24):3443-53. doi: 10.1111/bph.13575

50. Daoud J, Petropavlovskaia M, Rosenberg L, Tabrizian M. The effect of extracellular matrix components on the preservation of human islet function in vitro. Biomaterials (2010) 31(7):1676-82. doi: 10.1016/ j.biomaterials.2009.11.057

51. Daoud JT, Petropavlovskaia MS, Patapas JM, Degrandpré CE, Diraddo RW, Rosenberg L, et al. Long-term in vitro human pancreatic islet culture using three-dimensional microfabricated scaffolds. Biomaterials (2011) 32(6):153642. doi: 10.1016/j.biomaterials.2010.10.036

52. Buitinga M, Truckenmüller R, Engelse MA, Moroni L, Ten Hoopen HWM, van Blitterswijk CA, et al. Microwell scaffolds for the extrahepatic transplantation of islets of Langerhans. PloS One (2013) 8(5):e64772. doi: 10.1371/journal.pone.0064772

53. Komatsu H, Rawson J, Medrano L, Cook CA, Barriga A, Gonzalez N, et al. Optimizing Temperature and Oxygen Supports Long-term Culture of
Human Islets. Transplantation (2018) 103(2):299-306. doi: 10.1097/ TP.0000000000002280

54. Kim DS, Song L, Wang J, Wu H, Gou W, Cui W, et al. Carbon Monoxide Inhibits Islet Apoptosis via Induction of Autophagy. Antioxid Redox Signal (2018) 28(14):1309-22. doi: 10.1089/ars.2016.6979

55. Momeni M, Zarehaghighi M, Hajimiri M, Khorasani G, Dinarvand R, Nekookar A, et al. In vitro and in vivo investigation of a novel amnioticbased chitosan dressing for wound healing. Wound Repair Regener (2018) 26 (1):87-101. doi: 10.1111/wrr.12618

56. Qureshi KM, Oliver RJ, Paget MB, Murray HE, Bailey CJ, Downing R, et al. Human amniotic epithelial cells induce localized cell-mediated immune privilege in vitro: implications for pancreatic islet transplantation. Cell Transplant (2011) 20(4):523-34. doi: 10.3727/096368910X528111

57. Lebreton F, Lavallard V, Bellofatto K, Bonnet R, Wassmer CH, Perez L, et al. Insulin-producing organoids engineered from islet and amniotic epithelial cells to treat diabetes. Nat Commun (2019) 10(1):4491. doi: 10.1038/s41467019-12472-3

58. Cui W, Khan KM, Ma X, Chen G, Desai CS. Human Amniotic Epithelial Cells and Human Amniotic Membrane as a Vehicle for Islet Cell Transplantation. Transplant Proc (2020) 52(3):982-6. doi: 10.1016/j.transproceed.2020.01.022

59. Faridvand Y, Nozari S, Atashkhoei S, Nouri M, Jodati A, et al. Amniotic membrane extracted proteins protect $\mathrm{H} 9 \mathrm{c} 2$ cardiomyoblasts against hypoxiainduced apoptosis by modulating oxidative stress. Biochem Biophys Res Commun (2018) 503(3):1335-41. doi: 10.1016/j.bbrc.2018.07.045

60. Hers I, Vincent EE, Tavaré JM. Akt signalling in health and disease. Cell Signal (2011) 23(10):1515-27. doi: 10.1016/j.cellsig.2011.05.004

61. Zhang BK, Moran AM, Bailey CG, Rasko JEJ, Holst J, Wang Q, et al. EGFactivated PI3K/Akt signalling coordinates leucine uptake by regulating LAT3 expression in prostate cancer. Cell Commun Signal (2019) 17(1):83. doi: 10.1186/s12964-019-0400-0

62. Contreras JL, Smyth CA, Bilbao G, Young CJ, Thompson JA, Eckhoff DE, et al. Simvastatin induces activation of the serine-threonine protein kinase $\mathrm{AKT}$ and increases survival of isolated human pancreatic islets. Transplantation (2002) 74(8):1063-9. doi: 10.1097/00007890-20021027000001

63. Li C, Yang B, Xu Z, Boivin E, Black M, Huang W, et al. Protective effect of cyanidin-3-O-glucoside on neonatal porcine islets. J Endocrinol (2017) 235 (3):237-49. doi: 10.1530/JOE-17-0141

64. Li Z, Shangguan Z, Liu Y, Wang J, Li X, Yang S, et al. Puerarin protects pancreatic beta-cell survival via PI3K/Akt signaling pathway. J Mol Endocrinol (2014) 53(1):71-9. doi: 10.1530/JME-13-0302

65. Paraskevas S, Aikin R, Maysinger D, Lakey JR, Cavanagh TJ, Hering B, et al. Activation and expression of ERK, JNK, and p38 MAP-kinases in isolated islets of Langerhans: implications for cultured islet survival. FEBS Lett (1999) 455(3):203-8. doi: 10.1016/S0014-5793(99)00882-0

66. Zhang C, Li L, Zhao B, Jiao A, Li X, Sun N, et al. Ghrelin Protects against Dexamethasone-Induced INS-1 Cell Apoptosis via ERK and p38MAPK Signaling. Int J Endocrinol (2016) 2016:4513051. doi: 10.1155/2016/4513051

Conflict of Interest: The authors declare that the research was conducted in the absence of any commercial or financial relationships that could be construed as a potential conflict of interest.

Copyright $\odot 2020$ Yang, Li, Zhang, Sun, Guo, Lin, Li and Zhang. This is an openaccess article distributed under the terms of the Creative Commons Attribution License (CC BY). The use, distribution or reproduction in other forums is permitted, provided the original author(s) and the copyright owner(s) are credited and that the original publication in this journal is cited, in accordance with accepted academic practice. No use, distribution or reproduction is permitted which does not comply with these terms. 